\title{
The Stability of Banks' Retail Deposits at the Early Stages of Covid-19 Pandemic: A Preliminary Evidence from Euro Area
}

\author{
Paolo Agnese ${ }^{1}$ and Gianfranco A. Vento ${ }^{2}$
}

\begin{abstract}
In this paper we analyze trends of euro area banks' retail deposits at the early stages of Covid19. It emerges that overnight and total deposits placed by households and non-financial corporations in the major euro area countries (Germany, France, Italy and Spain) are "sluggish" and "sticky" even in an extraordinary period characterized by unexpected shocks due to the ongoing pandemic. All this for the benefit of solidity of the European banking and financial system and, more broadly, of the systemic risk.
\end{abstract}

JEL classification number: G21.

Keywords: Covid-19, Banks' retail deposits, Households and non-financial corporations, Euro area.

\footnotetext{
1 UNINETTUNO University, Rome, Italy. LUMSA University, Rome, Italy.

2 GUGLIELMO MARCONI University, Rome, Italy.
} 


\section{Introduction}

The Covid-19 pandemic has led the global economy into a recession of uncertain magnitude and duration, as the effects of past epidemics provide little guidance to predict the impact of the ongoing pandemic. Many sectors of the economy, such as tourism, transportation, automotive and services, are experiencing heavy falls in turnover. Mainly thanks to the G20 financial regulatory reforms starting from the financial crisis of 2008-2009, the financial and banking systems are more resilient to these unprecedented shocks ${ }^{3}$. In fact, banks now have higher capital and liquidity buffers, as well as a healthier funding mix. However, banks and markets are facing growing challenges both in lending and funding activities (European Banking Authority 2020, Financial Stability Board 2020).

With reference to bank funding, we analyze the effects of Covid-19 pandemic on the evolution of banks' retail deposits in the euro area. In detail, we show the stability of bank deposits from households and from non-financial corporations in the early stages of Covid-19 pandemic, within the top four euro area countries (Germany, France, Italy, Spain).

The rest of the paper is organized as follows. A brief overview of the literature on bank deposits is presented below. Then, we show the impact of Covid-19 pandemic on the outstanding amounts of euro area banks' retail deposits. Lastly, we summarize the key considerations of the paper and propose some final considerations.

\section{The literature on bank deposits: a brief overview}

As it is known, banks seek funding from retail and wholesale sources. Retail funding consists of deposits from the non-financial private sector, predominantly from households. Wholesale funds, on the other hand, consist broadly of funding from private markets. With reference to the short-term, wholesale sources include interbank liabilities and other short-term debt, most notably repurchase agreements (repos), commercial paper and certificates of deposit. For longer maturities, banks issue medium-term notes and bonds. In addition, banks receive liquidity from monetary authorities. Capital is also part of bank funding (European Central Bank 2016, Van Rixtel and Gasperini 2013).

Retail deposits are generally the largest component of bank funding. "Deposits from households and non-financial corporations remain the main component of EU banks' funding" (European Banking Authority 2018, p. 7). Figure 1, that presents the evolution of the main liabilities of euro area banks (outstanding amounts at the end of the period, in EUR millions), confirms the importance of retail deposits as the primary source of bank funding in the euro area.

\footnotetext{
${ }^{3}$ For details on the G20 financial regulatory reforms, see Bank for International Settlements (2017).
} 


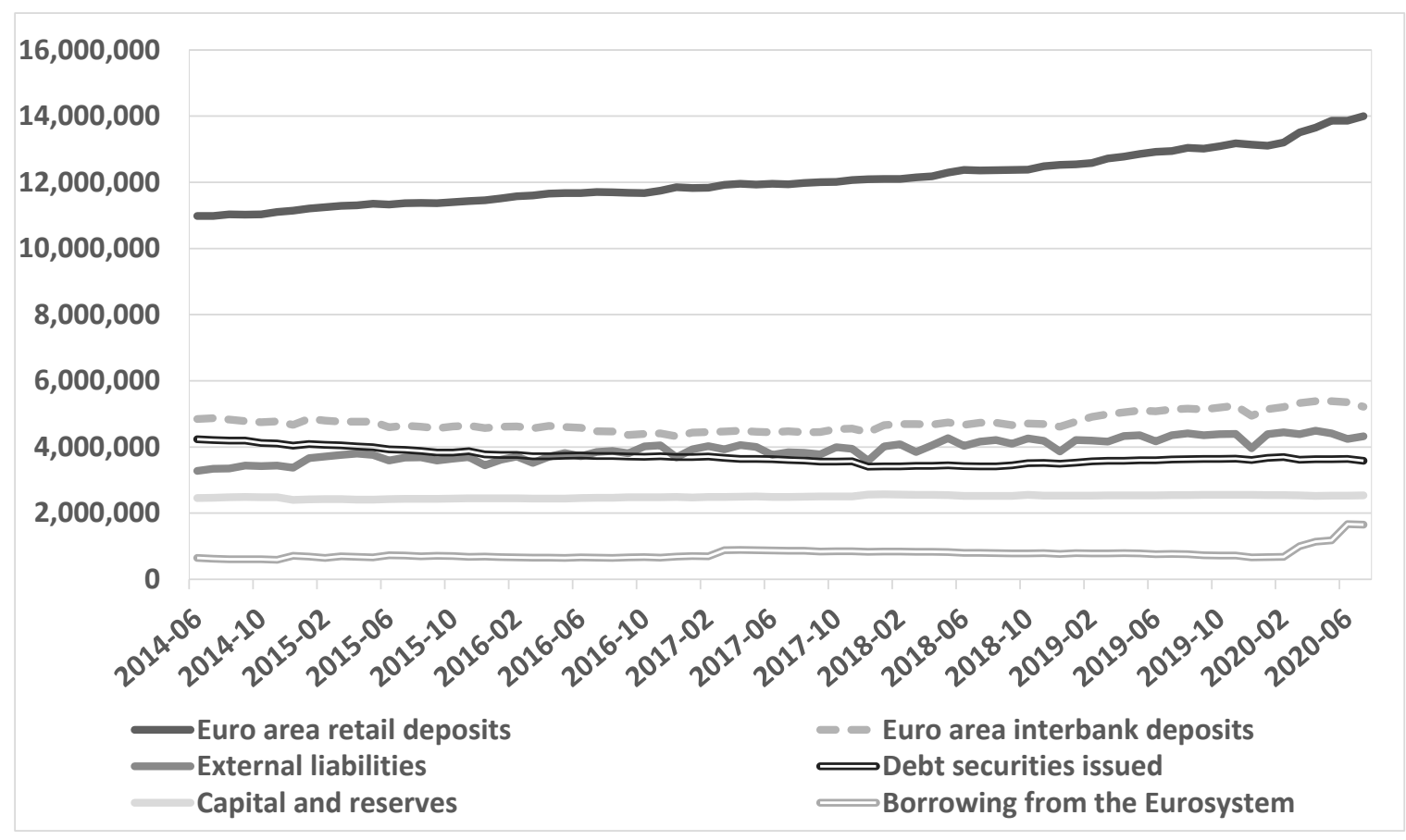

Figure 1: Main liabilities of euro area banks (EUR millions).

The figure shows the evolution of the main liabilities of euro area banks (outstanding amounts at the end of the period). Euro area retail deposits: deposit liabilities vis-a-vis euro area non-MFI excluding central government reported by MFI excluding ESCB in the euro area (stock). Euro area interbank deposits: deposits vis-a-vis euro area deposit-taking corporations except the central bank reported by MFIs excluding ESCB in the euro area (stock). Debt securities issued: debt securities issued reported by MFI excluding ESCB in the euro area (stock). External liabilities: external liabilities reported by $M F I$ excluding ESCB in the euro area (stock). Capital and reserves: capital and reserves reported by MFI excluding ESCB in the euro area (stock). Borrowing from the Eurosystem: deposits vis-a-vis the Eurosystem reported by MFIs excluding ESCB in the euro area (stock). Data are from ECB "Statistical Data Warehouse", https://sdw.ecb.europa.eul.

Furthermore, retail deposits tend to be less volatile than wholesale sources. This is for a variety of reasons, including transaction and switching costs and greater predictability based on the law of large numbers. In addition, retail deposits are "sluggish", insensitive to risks and more "sticky" than wholesale liabilities. Indeed, they are less subject to withdrawals related to uncertainty, in view of the fact that they are normally insured up to a certain amount by guarantee schemes ${ }^{4}$. Their withdrawals are determined, above all, by the liquidity needs of the depositors (European Central Bank 2016, Huang and Ratnovski 2011, Song and Thakor 2007, Van Rixtel and Gasperini 2013). On the contrary, wholesale funds are relatively sophisticated, because their holders are usually more interested in the bank solidity (Huang and Ratnovski 2011). Deposits stability also appears to be registered when negative interest rates are applied to them ${ }^{5}$. Altavilla et al. (2019), among other things, show that banks do not register a contraction in deposits when they charge negative interest rates. On the contrary, when the zero lower bound has been hit, demand for liquidity and safe assets grows.

\footnotetext{
4 Diamond and Dybvig (1983) show that the deposit insurance is a determining factor also in preventing bank runs.

5 However, several studies show that banks are reluctant to charge negative rates to a portion of their deposits when the monetary policy rates turn negative (Bech and Malkhozov 2016, Brei et al. 2019, Claessens et al. 2017, Eisenschmidt and Smets 2018, European Central Bank 2016, Heider et al. 2018).
} 


\section{Banks' retail deposits and Covid-19 pandemic: what impacts?}

The data are collected using "Euro area statistics", a website provided by the European Central Bank (ECB) and the national central banks (NCBs) of the Eurosystem. In particular, the analysis includes both total bank deposits and overnight bank deposits from households and non-financial corporations in the major four euro area countries, based on the highest GDP. The top four euro area countries that recorded the highest GDP in 2019, in order of decreasing GDP, are the following: Germany, France, Italy, Spain (Eurostat 2020). The stocks of retail deposits considered refer to the banks' balance sheet.

Figures 2 and 3 show, respectively, the evolution of overnight and total deposits placed by households in the four euro area countries considered, including non-profit institutions serving households. Instead, figures 4 and 5 show, respectively, the evolution of overnight and total deposits placed by non-financial corporations in the four euro area countries considered.

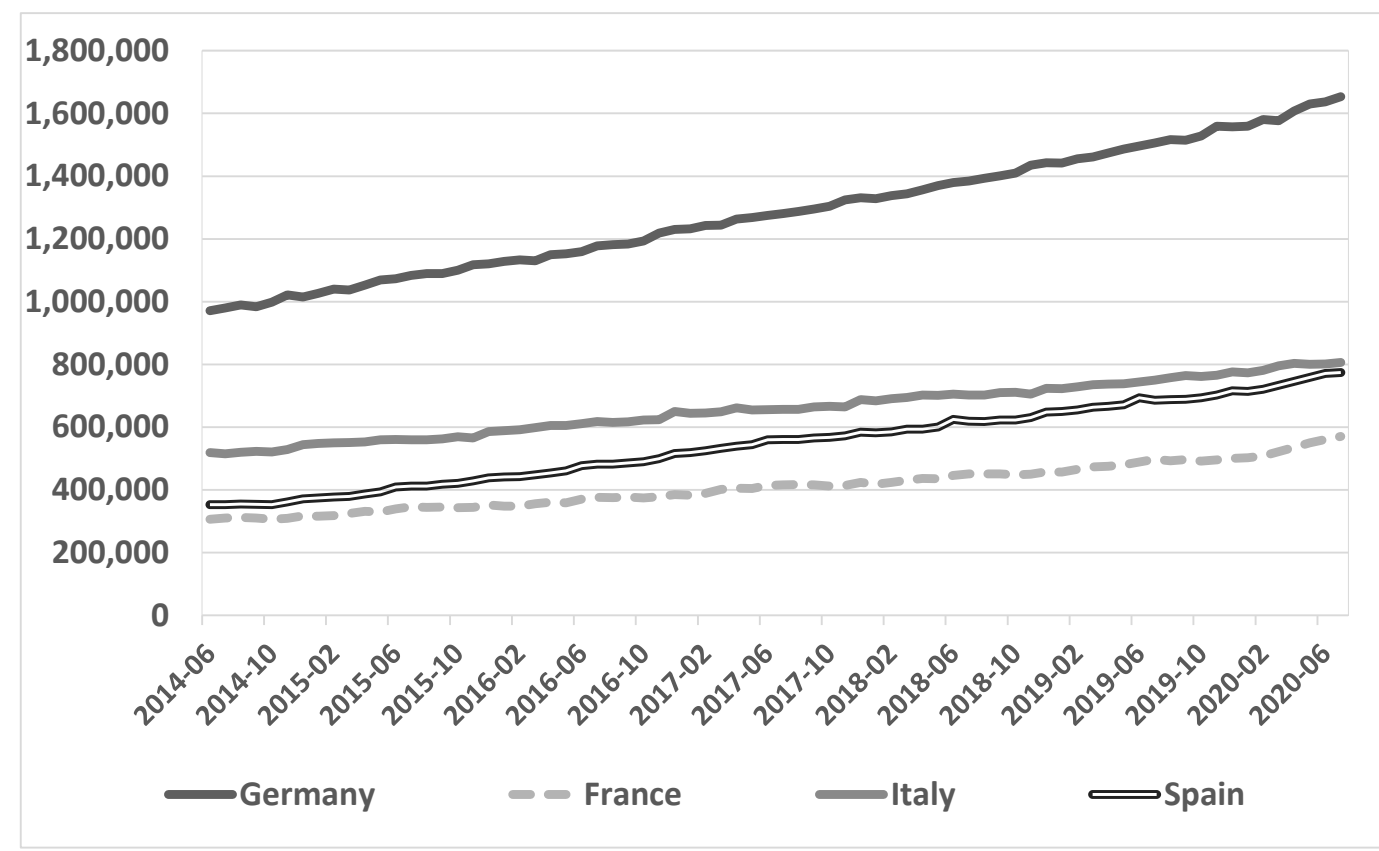

Figure 2: Overnight deposits from households (EUR millions) - Monetary financial institution balance sheet statistics.

The figure shows the evolution of overnight deposits placed by households in the major four euro area countries in terms of GDP, including non-profit institutions serving households. Data are from "Euro area statistics", https://www.euro-area-statistics.org/. 


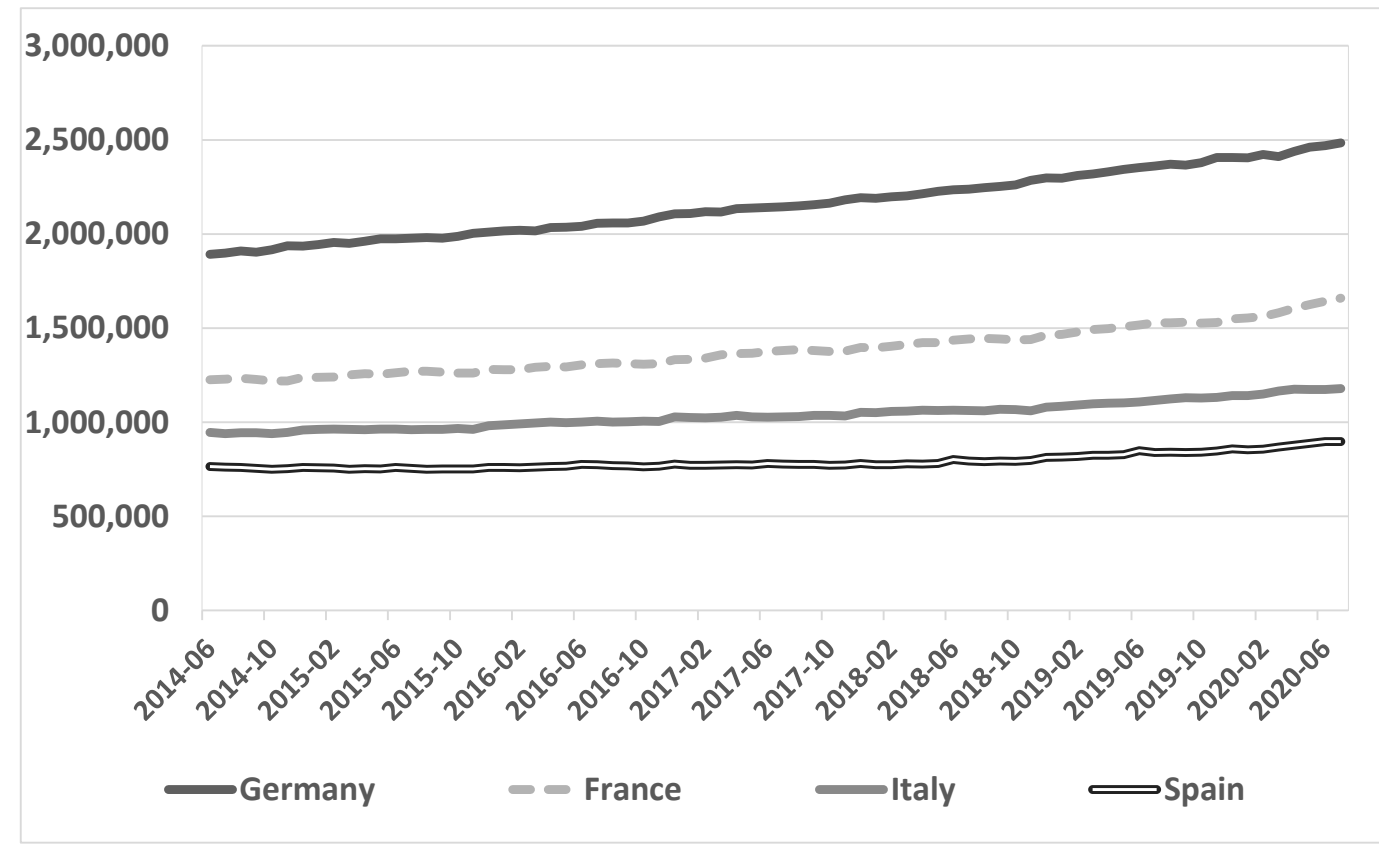

Figure 3: Total deposits from households (EUR millions) - Monetary financial institution balance sheet statistics.

The figure shows the evolution of total deposits placed by households in the major four euro area countries in terms of GDP, including non-profit institutions serving households. Data are from "Euro area statistics", https://www.euro-area-statistics.org/.

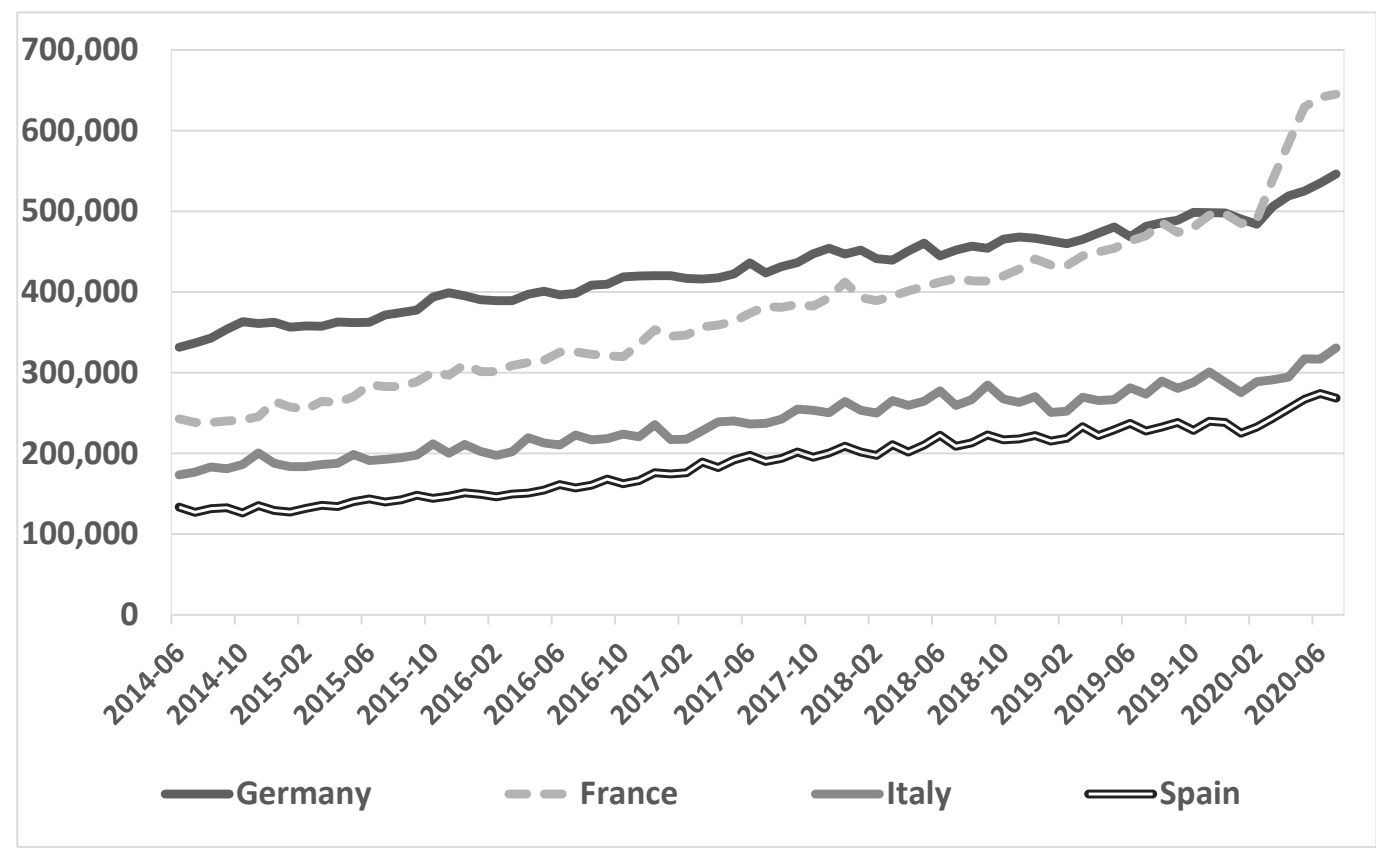

Figure 4: Overnight deposits from non-financial corporations (EUR millions) - Monetary financial institution balance sheet statistics.

The figure shows the evolution of overnight deposits placed by non-financial corporations in the major four euro area countries in terms of GDP. In accordance with the ESA 2010, in December 2014 holding companies of non-financial groups were reclassified from the non-financial corporations sector to the financial corporations sector. These entities are included in MFI balance sheet statistics with financial corporations other than MFIs and insurance corporations and pension funds (ICPFs). Data are from "Euro area statistics", https://www.euro-area-statistics.org/. 


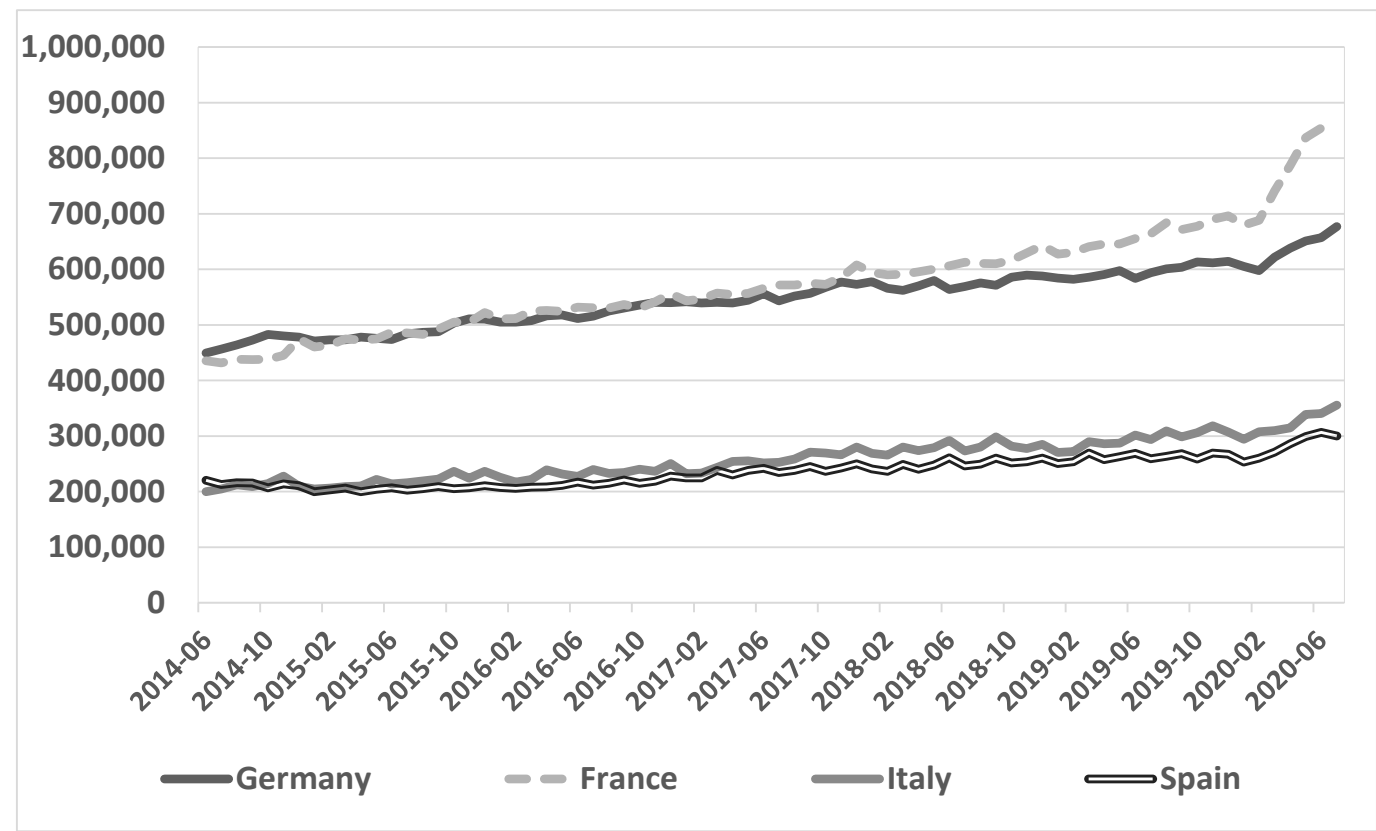

Figure 5: Total deposits from non-financial corporations (EUR millions) - Monetary financial institution balance sheet statistics.

The figure shows the evolution of total deposits placed by non-financial corporations in the major four euro area countries in terms of GDP. In accordance with the ESA 2010, in December 2014 holding companies of non-financial groups were reclassified from the non-financial corporations sector to the financial corporations sector. These entities are included in MFI balance sheet statistics with financial corporations other than MFIs and insurance corporations and pension funds (ICPFs). Data are from "Euro area statistics", https://www.euro-area-statistics.org/.

By analyzing the figures in question (figures 2 to 5), it clearly emerges that during the early stages of Covid-19 pandemic the euro area bank deposits (both from households and nonfinancial corporations), were not only stable but they also recorded increasing trends, especially in the case of deposits placed by corporates. All this considering a very low or zero remuneration paid to depositors, in some cases even negative, especially with reference to deposits placed by non-financial corporations. These trends could depend on the fears of households and corporates, in terms of consumption and investments, about the evolution of the current economic and financial condition, as well as the lack of confidence in the economic recovery in the short to medium run.

The trends of the figures presented confirm what the literature cited above has shown, namely that retail deposits are more stable than wholesale sources, as well as being "sluggish", insensitive to risks and more "sticky" than the latter, as they are less subject to withdrawals related to uncertainty (European Central Bank 2016, Huang and Ratnovski 2011, Song and Thakor 2007, Van Rixtel and Gasperini 2013).

\section{Final considerations}

The analysis of the evolution of retail liabilities shows that deposits from households and from corporates in the top four euro area countries in terms of GDP (Germany, France, Italy and Spain) are a stable and reliable source of funding for banks, even during the current Covid-19 pandemic period, characterized by global recessions of uncertain magnitudes and durations. Besides considering the fact that it all adds up to a very low or zero, or negative remuneration for depositors, in the latter case especially with reference to deposits from non-financial corporations. 
All this requires banks to rethink their funding mix strategy in the medium and long term, in order also to further strengthen the solidity of the euro area banking and financial system, as well as in order to better mitigate the systemic risk.

\section{References}

[1] Altavilla, C., Burlon, L., Giannetti, M. and Holton, S. (2019). Is there a zero lower bound? The effects of negative policy rates on banks and firms. ECB Working Paper Series No. 2289, June.

[2] Bank for International Settlements (2017). Basel III: Finalising post-crisis reforms. Basel Committee on Banking Supervision, December 2017.

[3] Bech, M. and Malkhozov, A. (2016). How have central banks implemented negative policy rates?. BIS Quarterly Review, March, pp. 31-44.

[4] Brei, M., Borio, C. and Gambacorta, L. (2019). Bank intermediation activity in a low interest rate environment. BIS Working Papers No. 807, August.

[5] Claessens, S., Coleman, N. and Donnelly, M. (2017). "Low-For-Long" Interest Rates and Banks' Interest Margins and Profitability: Cross-Country Evidence. International Finance Discussion Papers No. 1197, February.

[6] Diamond, D.W. and Dybvig, P.H. (1983). Bank Runs, Deposit Insurance, and Liquidity. Journal of Political Economy, Vol. 91, No. 3, pp. 401-419.

[7] Eisenschmidt, J. and Smets, F. (2018). Negative interest rates: Lessons from the Euro Area. Working paper, March.

[8] European Banking Authority (2020). The EU Banking Sector: first insights into the Covid-19 impacts. Thematic Note EBA/REP/2020/17.

[9] European Banking Authority (2018). EBA Report on Funding Plans, September 2018.

[10] European Central Bank (2016). Recent developments in the composition and cost of bank funding in the euro area. Economic Bulletin, Issue 1 / 2016, pp. 26-42.

[11] Eurostat (2020). Which EU countries had the highest GDP in 2019?. https://ec.europa.eu/eurostat/web/products-eurostat-news/-/DDN-20200508-1.

[12] Financial Stability Board (2020). COVID-19 pandemic: Financial stability implications and policy measures taken. 15 April 2020.

[13] Heider, F., Saidi, F. and Schepens, G. (2018). Life below zero: bank lending under negative policy rates. ECB Working Paper Series No. 2173, August.

[14] Huang, R. and Ratnovski, L. (2011). The dark side of bank wholesale funding. Journal of Financial Intermediation, Vol. 20, No. 2, pp. 248-263.

[15] Song, F. and Thakor, A.V. (2007). Relationship Banking, Fragility, and the AssetLiability Matching Problem. The Review of Financial Studies, Vol. 20, No. 5, pp. 21292177.

[16] Van Rixtel, A. and Gasperini, G. (2013). Financial crises and bank funding: recent experience in the euro area. BIS Working Papers No. 406, March. 